\title{
Prenyleudesmanes and A Hexanorlanostane from the Roots of Lonicera macranthoides
}

\author{
Hui Lyu ${ }^{1,2,+}$, Wenjuan Liu ${ }^{3,+}{ }^{\dagger}$, Bai Bai ${ }^{1}$, Yu Shan ${ }^{1}$, Christian Paetz ${ }^{2} \mathbb{1}$, Xu Feng ${ }^{1, *}$ and Yu Chen ${ }^{1, *}$ \\ 1 Jiangsu Key Laboratory for the Research and Utilization of Plant Resources, The Jiangsu Provincial Platform \\ for Conservation and Utilization of Agricultural Germplasm, Institute of Botany, Jiangsu Province and \\ Chinese Academy of Sciences, Nanjing 210000, China; hlyu@ice.mpg.de (H.L.); baibai0924@126.com (B.B.); \\ shanyu79@126.com (Y.S.) \\ 2 Max Planck Institute for Chemical Ecology, D-07745 Jena, Germany; cpaetz@ice.mpg.de \\ 3 Naval Compound Community Health Care Station, Beijing 100853, China; wenjuan9718@sina.com \\ * Correspondence: fengxucnbg@mail.cnbg.net (X.F.); yuchen1007@hotmail.com (Y.C.); \\ Tel.: +86-25-84347158 (X.F.); +86-25-84347116 (Y.C.) \\ + These two authors contributed equally to this work.
}

Received: 22 October 2019; Accepted: 21 November 2019; Published: 23 November 2019

check for updates

\begin{abstract}
Three previously undescribed compounds, two prenyleudesmanes (1 and 2), and one hexanorlanostane (3), were isolated from the roots of Lonicera macranthoides. Their structures were established based on 1D and 2D nuclear magnetic resonance (NMR) spectra and high-resolution electrospray ionization mass spectral (HR-ESI-MS) data. The absolute configurations of $\mathbf{1}$ and $\mathbf{3}$ were determined by X-ray diffraction. To the best of our knowledge, this is the first time that the absolute configuration of a prenyleudesmane with a trans-decalin system and a hexanorlanostane have been unambiguously confirmed by single-crystal $\mathrm{X}$-ray diffraction with $\mathrm{Cu} \mathrm{K} \alpha$ radiation. Thecompounds were tested for their antiproliferative activity on the cancer cell lines (HepG2 and HeLa). The compounds 1-3 exhibited moderate inhibitory effects against two human cancer cell lines.
\end{abstract}

Keywords: Lonicera macranthoides; Caprifoliaceae; Prenyleudesmanes; Hexanortriterpenes; Antiproliferative

\section{Introduction}

Lonicera macranthoides Hand.-Mazz., a plant of the genus Lonicera in the family Caprifoliaceae, is mainly distributed in the southwest of China [1]. The dried flower buds of L. macranthoides are commonly used as a raw material in traditional Chinese medicine for treating fever, inflammation, and infectious diseases [2]. Earlier phytochemical studies on the plant have shown the presence of various triterpenoid saponins (e.g., hederagenin saponins, oleanolic acid saponins, 18-oleanene saponins, and lupane saponins) [3-6], flavonoids [7], phenolic acids [8,9], and iridoids [8,9] in aerial parts and flowers of the plant. Because of our studies of L. macranthoides, we became interested in the diterpenes of this species. Recently, we reported the first known occurrence of diterpenes (e.g., labdane, aphidicolane, and syn-pimarane) in the roots of L. macranthoides [10-12]. To explore further unknown diterpenes, we reinvestigated the roots of L. macranthoides. Here, we report on the isolation and characterization of two new diterpenes, lonimacranthoidin C (1) and lonimacranthoidin D (2), and a novel hexanorlanostane, lonimacranthoidin E (3). Compounds 1-3 were screened for antiproliferative activity against two human cancer cell lines, HepG2 and HeLa.

\section{Results and Discussion}

An ethanolic extract of dried roots of L. macranthoides was suspended in water and partitioned sequentially between petroleum ether and ethyl acetate (EtOAc). The EtOAc fraction was subjected 
to repeated separation by column chromatography (CC) over silica gel and Sephadex LH-20. Selected fractions were further purified by preparative HPLC to yield three pure compounds, including the two prenyleudesmanes $(\mathbf{1}, \mathbf{2})$ and a hexanorlanostane (3), as seen in Figure 1 . The structure elucidation was carried out by high-resolution mass spectrometry (HRMS), nuclear magnetic resonance (NMR) spectroscopy $\left({ }^{1} \mathrm{H} \mathrm{NMR},{ }^{13} \mathrm{C} \mathrm{NMR},{ }^{1} \mathrm{H}-{ }^{1} \mathrm{H}\right.$ homonuclear chemical shift correlation spectroscopy (COSY), ${ }^{1} \mathrm{H}-{ }^{13} \mathrm{C}$ heteronuclear single quantum coherence (HSQC), ${ }^{1} \mathrm{H}-{ }^{13} \mathrm{C}$ heteronuclear multiple bond correlation (HMBC), and ${ }^{1} \mathrm{H}_{-}{ }^{1} \mathrm{H}$ rotating frame Overhauser effect spectroscopy (ROESY)), and single-crystal $\mathrm{X}$-ray diffraction analysis.

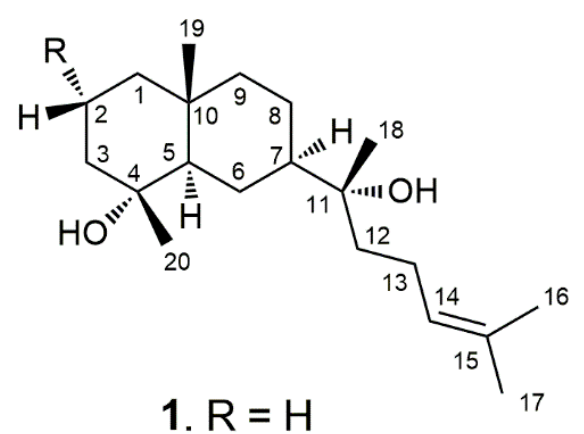

2. $\mathrm{R}=\mathrm{OH}$

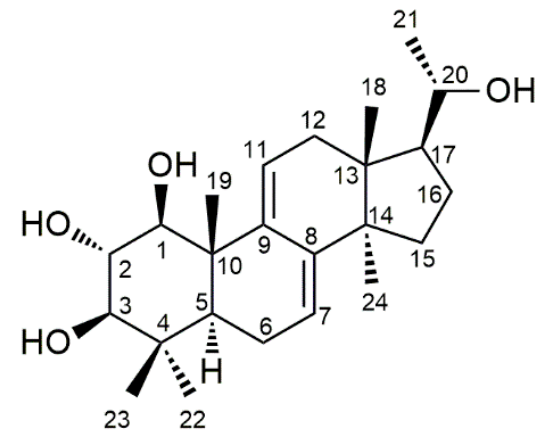

3

Figure 1. Chemical structures of the compounds 1-3.

Compound 1 was obtained as colorless crystals. The molecular formula of $\mathrm{C}_{20} \mathrm{H}_{36} \mathrm{O}_{2} \mathrm{Na}$ was determined by the pseudomolecular ion peak at $m / z 331.2607[\mathrm{M}+\mathrm{Na}]^{+}$(calculated: 331.2608 ) in positive HR-ESI-MS, corresponding to three unsaturations. The UV spectrum showed the absorption maximum at $\lambda_{\max } 201 \mathrm{~nm}$. The compound showed a positive optical rotation of $[\alpha]_{\mathrm{D}}^{25}+26.4$ (c 0.100 in methanol). The ${ }^{1} \mathrm{H}$ NMR spectrum of 1 displayed signals for one olefinic proton at $\delta_{\mathrm{H}} 5.14(1 \mathrm{H}$, $\mathrm{dd}, J=7.0 / 7.0, \mathrm{H}-14)$, five methyl singlets at $\delta_{\mathrm{H}} 0.86\left(3 \mathrm{H}, \mathrm{s}, \mathrm{H}_{3}-19\right), \delta_{\mathrm{H}} 1.11\left(3 \mathrm{H}, \mathrm{s}, \mathrm{H}_{3}-20\right), \delta_{\mathrm{H}} 1.16$ $\left(3 \mathrm{H}, \mathrm{s}, \mathrm{H}_{3}-18\right), \delta_{\mathrm{H}} 1.63\left(3 \mathrm{H}, \mathrm{s}, \mathrm{H}_{3}-17\right)$, and $\delta_{\mathrm{H}} 1.69\left(3 \mathrm{H}, \mathrm{s}, \mathrm{H}_{3}-16\right)$, and overlapping aliphatic methylene and/or methine signals $\left(\delta_{\mathrm{H}}\right.$ 1.05-2.04). The assignment of the latter could be accomplished by a series of selective total correlation spectroscopy (SELTOCSY) experiments (see Supporting Information). The ${ }^{13} \mathrm{C}$ NMR and distortionless enhancement by polarization transfer (DEPT) NMR spectra of 1 showed the presence of 20 carbon resonances, including two signals of olefinic carbons at $\delta_{\mathrm{C}} 124.6$ $(\mathrm{C}-14)$ and $\delta_{\mathrm{C}} 131.6(\mathrm{C}-15)$, five signals for methyl groups at $\delta_{\mathrm{C}} 17.6(\mathrm{C}-16), \delta_{\mathrm{C}} 18.7(\mathrm{C}-19), \delta_{\mathrm{C}} 22.6$ $(\mathrm{C}-20), \delta_{\mathrm{C}} 24.1(\mathrm{C}-18)$, and $\delta_{\mathrm{C}} 25.7(\mathrm{C}-17)$, eight methylene signals at $\delta_{\mathrm{C}} 41.0(\mathrm{C}-1), \delta_{\mathrm{C}} 20.1(\mathrm{C}-2), \delta_{\mathrm{C}}$ $43.5(\mathrm{C}-3), \delta_{\mathrm{C}} 21.4(\mathrm{C}-6), \delta_{\mathrm{C}} 21.8(\mathrm{C}-8), \delta_{\mathrm{C}} 44.6(\mathrm{C}-9), \delta_{\mathrm{C}} 39.7(\mathrm{C}-12)$, and $\delta_{\mathrm{C}} 22.3(\mathrm{C}-13)$, two methine signals at $\delta_{C} 55.0(\mathrm{C}-5)$ and $\delta_{C} 48.3(\mathrm{C}-7)$, one signal for a quaternary carbon at $\delta_{\mathrm{C}} 34.6(\mathrm{C}-10)$, and two signals of oxygenated tertiary carbons at $\delta_{C} 72.3(\mathrm{C}-4)$ and $\delta_{C} 74.5(\mathrm{C}-11)$. The interpretation of NMR spectra and the degree of unsaturation deduced from HRMS data suggested that compound 1 was a bicyclic diterpene possessing a trisubstituted double bond and two hydroxyl groups $(\mathrm{OH}-4$ and $\mathrm{OH}-11)$. Analysis of the ${ }^{1} \mathrm{H}_{-}{ }^{1} \mathrm{H}$ COSY and HSQC spectra of $\mathbf{1}$ provided three partial structures shown by bold lines in Figure 2. The interpretation of the HMBC spectrum of 1 showed correlations from $\mathrm{H}_{3}-17$ to $\mathrm{C}-14, \mathrm{C}-15$, and $\mathrm{C}-16$, and from $\mathrm{H}_{3}-16$ to $\mathrm{C}-14, \mathrm{C}-15$, and $\mathrm{C}-17$; these enabled the localization of the double bond at $\mathrm{C}-14$. This spin system is further characterized by a coupling of $\mathrm{H}-12$ to $\mathrm{H}-14$. HMBC correlations from $\mathrm{H}-12$ to $\mathrm{C}-11$, and from $\mathrm{H}_{3}-18$ to $\mathrm{C}-11$ and $\mathrm{C}-12$, eventually resulted in the definition of a side chain of eight carbons, including a trisubstituted double bond $\left(\Delta^{14}\right)$. A further HMBC correlation from $\mathrm{H}-12$ to $\mathrm{C}-7$ and from $\mathrm{H}_{3}-18$ to $\mathrm{C}-7$ indicated the linkage to $\mathrm{C}-7$ of the decalin ring system. The two hydroxylated positions at C-4 and C-11, respectively, could be confirmed by the HMBC correlations from $\mathrm{H}_{3}-20$ to $\mathrm{C}-3, \mathrm{C}-4$, and $\mathrm{C}-5$, and from $\mathrm{H}_{3}-18$ to C-11 and C-12, as seen in Figure 2. In summary, the NMR data analysis, as seen in Table 1, revealed 
a prenyleudesmane skeleton similar to dysokusone A [13], and the structure of 1 was determined as shown in Figure 1. The relative configuration of $\mathbf{1}$ was partially established by analyzing its ROESY correlations. Nuclear Overhauser effect (NOE) correlations between $\mathrm{H}_{3}-18, \mathrm{H}_{3}-19$, and $\mathrm{H}_{3}-20$ suggested a cofacial arrangement. Finally, crystals of compound $\mathbf{1}$ were obtained and subjected to $\mathrm{X}$-ray diffraction analysis, as seen in Figure 3. The absolute configuration of $\mathbf{1}$ was determined as (4R,5R,7R,10R)-4,10-dimethyl-7-(11R-hydroxy-11,15-dimethyl-14-ene-11-yl)-trans-decalin-4-ol by Cu X-ray crystallography (Flack parameter $=-0.05$ (11), Figure 3) [14,15] and named as lonimacranthoidin C (1). Ours was the first successful single-crystal X-ray analysis of a prenyleudesmane with a trans-decalin scaffold.
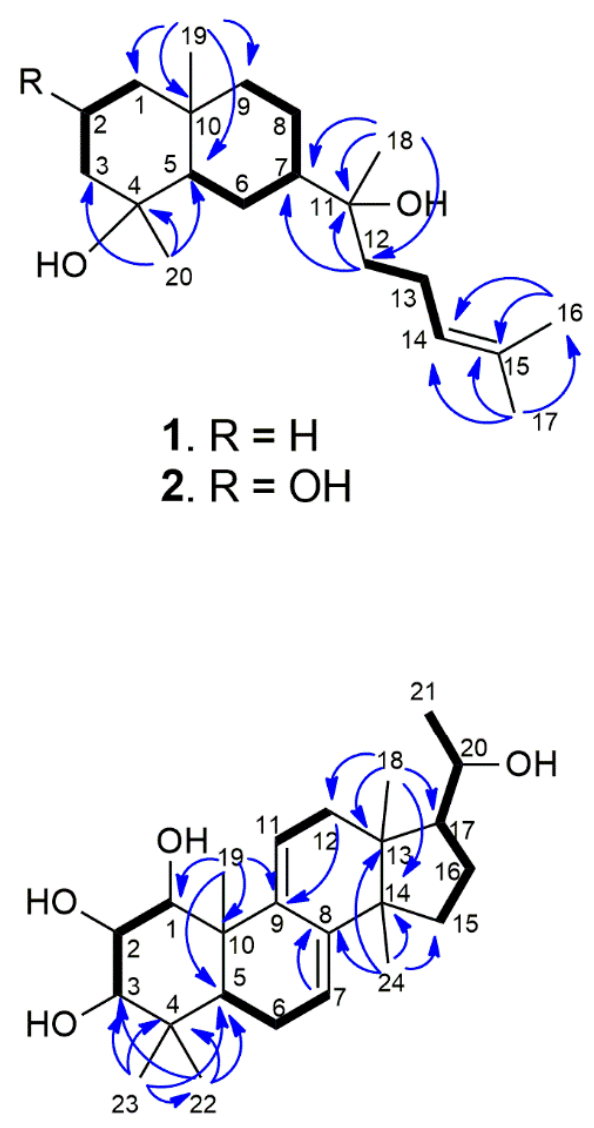

3

HMBC

${ }^{1} \mathrm{H}-{ }^{1} \mathrm{H} \operatorname{Cos} Y$

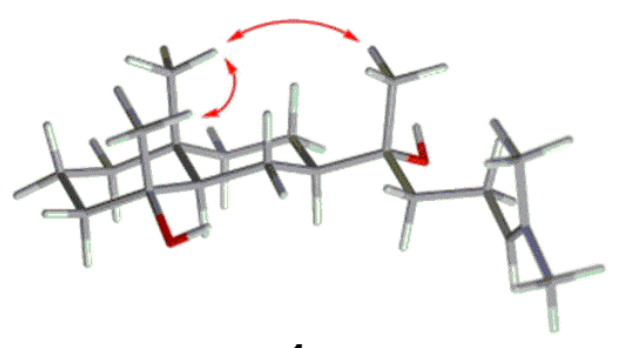

1
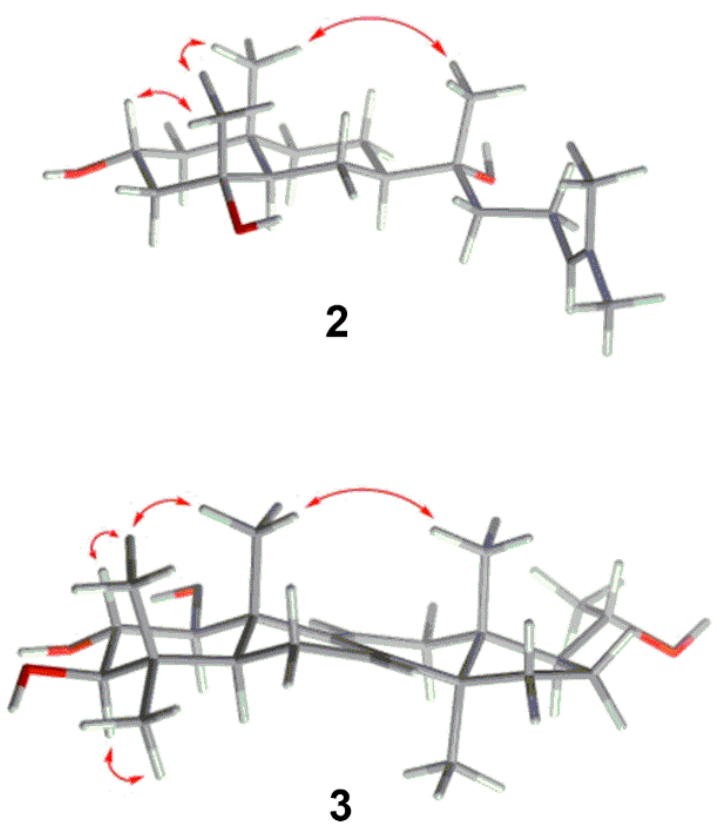

Figure 2. Key 2D NMR correlations of compounds 1, 2, and 3. 


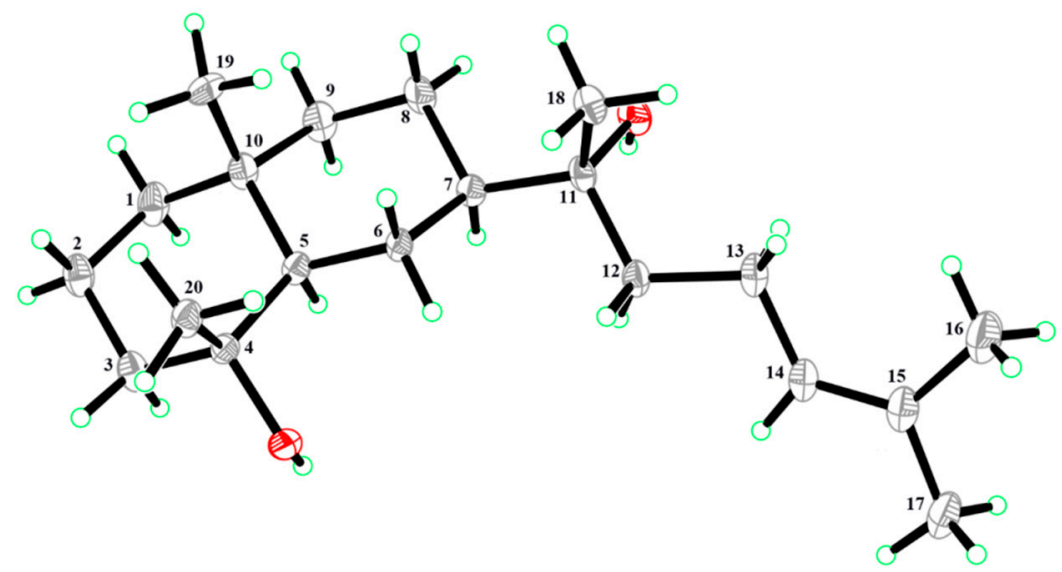

Figure 3. X-ray Oak Ridge thermal-ellipsoid plot program (ORTEP) drawing of compound 1.

Table 1. ${ }^{1} \mathrm{H}$ and ${ }^{13} \mathrm{C}$ NMR spectral data of compounds $\mathbf{1}, \mathbf{2}$, and 3.

\begin{tabular}{|c|c|c|c|c|c|c|}
\hline \multirow{2}{*}{ Atom } & \multicolumn{2}{|r|}{$1^{a, c}$} & \multicolumn{2}{|r|}{$2^{a, c}$} & \multicolumn{2}{|r|}{$3^{b, c}$} \\
\hline & $\delta_{\mathrm{C}}$ & $\delta_{\mathrm{H}}$ & $\delta_{\mathrm{C}}$ & $\delta_{\mathrm{H}}$ & $\delta_{\mathrm{C}}$ & $\delta_{\mathrm{H}}$ \\
\hline $1 \alpha$ & 41.0 & 1.07 ddd $12.5 / 12.5 / 6.0$ & 46.7 & $1.34 \mathrm{dd} 14.0 / 3.2$ & 78.4 & $3.57 \mathrm{~d} 10.0$ \\
\hline $1 \beta$ & & $1.38 \mathrm{~d} 12.5$ & & $1.67 \mathrm{~m}$ & & \\
\hline $2 \alpha$ & 20.1 & $1.58 \mathrm{~m}$ & 68.2 & 4.28 ddd $7.0 / 3.0 / 3.0$ & 72.9 & $3.48 \mathrm{dd} 10.0 / 10.0$ \\
\hline $2 \beta$ & & $1.56 \mathrm{~m}$ & & & & \\
\hline $3 \alpha$ & 43.5 & 1.35 ddd $12.5 / 12.5 / 5.5$ & 48.5 & $1.66 \mathrm{~m}$ & 78.7 & $3.04 \mathrm{~d} 10.0$ \\
\hline $3 \beta$ & & $1.79 \mathrm{~d} 12.5$ & & $2.01 \mathrm{~d} 14.0$ & & \\
\hline 4 & 72.3 & & 71.6 & & 38.1 & \\
\hline 5 & 55.0 & $1.19 \mathrm{~d} 12.5$ & 54.4 & $1.29 \mathrm{dd} 12.5 / 2.0$ & 47.1 & 1.16 dd $5.0 / 12.0$ \\
\hline $6 \alpha$ & 21.4 & $1.86 \mathrm{~d} 12.5$ & 21.2 & $1.87 \mathrm{~d} 12.5$ & 22.4 & $2.20 \mathrm{dd} 12.0 / 17.0$ \\
\hline $6 \beta$ & & 1.03 ddd $12.5 / 12.5 / 12.5$ & & 1.14 ddd $12.5 / 12.5 / 12.5$ & & 2.15 dd 5.0/5.0/17.0 \\
\hline 7 & 48.3 & 1.41 dddd $12.5 / 12.5 / 3.0 / 3.0$ & 48.5 & 1.42 dddd $12.5 / 12.5 / 3.0 / 3.0$ & 119.5 & $5.49 \mathrm{~d} 5.0$ \\
\hline $8 \alpha$ & 21.8 & $1.59 \mathrm{~d} 12.5$ & 21.2 & $1.56 \mathrm{~d} 12.5$ & 142.1 & \\
\hline $8 \beta$ & & 1.33 dddd $12.5 / 12.5 / 12.5 / 3.0$ & & 1.37 dddd $12.5 / 12.5 / 12.5 / 3.5$ & & \\
\hline $9 \alpha$ & 44.6 & 1.45 ddd $12.5 / 3.0 / 3.0$ & 44.9 & 1.49 ddd $12.5 / 3.0 / 3.0$ & 144.0 & \\
\hline $9 \beta$ & & 1.15 ddd $12.5 / 12.5 / 3.0$ & & $1.12 \mathrm{~m}$ & & \\
\hline 10 & 34.6 & & 34.0 & & 43.2 & \\
\hline 11 & 74.5 & & 74.6 & & 119.1 & $6.31 \mathrm{~d} 6.0$ \\
\hline $12 \alpha$ & 39.7 & $1.53 \mathrm{dd} 8.2 / 8.2$ & 39.5 & $1.52 \mathrm{dd} 8.1 / 8.1$ & 36.4 & $2.18 \mathrm{~d} 17.0$ \\
\hline $12 \beta$ & & & & & & $2.06 \mathrm{~d} 6.0 / 17.0$ \\
\hline 13 & 22.3 & $2.06 \mathrm{~m}$ & 22.3 & $2.04 \mathrm{~m}$ & 42.0 & \\
\hline 14 & 124.6 & 5.14 dd $7.0 / 7.0$ & 124.5 & 5.13 dd $6.7 / 6.7$ & 49.9 & \\
\hline $15 \alpha$ & 131.6 & & 131.6 & & 31.1 & 1.68 ddd $7.5 / 11.5 / 11.5$ \\
\hline $15 \beta$ & & & & & & $1.46 \mathrm{dd} 9.0 / 11.5$ \\
\hline $16 \alpha$ & 17.6 & $1.63 \mathrm{~s}$ & 17.8 & $1.62 \mathrm{~s}$ & 25.8 & 2.07 ddd 9.0/14.0/17.0 \\
\hline $16 \beta$ & & & & & & $1.60 \mathrm{dd} 9.0 / 14.0$ \\
\hline 17 & 25.7 & $1.69 \mathrm{~s}$ & 25.8 & $1.68 \mathrm{~s}$ & 53.0 & $1.78 \mathrm{dd} 9.0 / 17.0$ \\
\hline 18 & 24.1 & $1.16 \mathrm{~s}$ & 24.2 & $1.16 \mathrm{~s}$ & 15.4 & $0.57 \mathrm{~s}$ \\
\hline 19 & 18.7 & $0.86 \mathrm{~s}$ & 20.3 & $1.14 \mathrm{~s}$ & 15.9 & $1.06 \mathrm{~s}$ \\
\hline 20 & 22.6 & $1.11 \mathrm{~s}$ & 25.0 & $1.33 \mathrm{~s}$ & 70.4 & $3.62 \mathrm{dd} 6.2 / 9.0$ \\
\hline 21 & & & & & 22.4 & $1.21 \mathrm{~d} 6.2$ \\
\hline 22 & & & & & 15.9 & $0.90 \mathrm{~s}$ \\
\hline 23 & & & & & 27.6 & $1.02 \mathrm{~s}$ \\
\hline 24 & & & & & 24.9 & $0.91 \mathrm{~s}$ \\
\hline
\end{tabular}

${ }^{\text {a }}$ Data were measured at $500 \mathrm{MHz}$ for ${ }^{1} \mathrm{H}$ and $125 \mathrm{MHz}$ for ${ }^{13} \mathrm{C}$ in $\mathrm{CDCl}_{3} \delta$ in ppm, $J$ in $\mathrm{Hz} . ;{ }^{\mathrm{b}}$ Data were measured at $300 \mathrm{MHz}$ for ${ }^{1} \mathrm{H}$ and $75 \mathrm{MHz}$ for ${ }^{13} \mathrm{C}$ in $\mathrm{CDCl}_{3}: \mathrm{CD}_{3} \mathrm{OD}=1: 1, \delta$ in ppm, $J$ in $\mathrm{Hz} . ;{ }^{c}$ Overlapping signals were assigned by HSQC, HMBC, COSY, and SELTOCSY experiments.

Compound 2 was obtained as milky oil with the molecular formula $\mathrm{C}_{20} \mathrm{H}_{36} \mathrm{O}_{3}$ as determined by HR-ESI-MS ( $m / z 347.2551[\mathrm{M}+\mathrm{Na}]^{+}$, calculated: $m / z 347.2557$ for $\left.\left[\mathrm{C}_{20} \mathrm{H}_{36} \mathrm{O}_{3}+\mathrm{Na}\right]^{+}\right)$. Similar to 1, compound 2 showed three unsaturations. The UV spectrum of 2 showed an absorption at $\lambda_{\max } 201 \mathrm{~nm}$ and a positive optical rotation of $[\alpha]_{\mathrm{D}}^{25}+10.0$ (c 0.100 in methanol) was determined. The assignment of all proton and carbon chemical shifts of 2 was achieved by analyzing the 1D and 2D NMR spectra, as seen in Table 1. Similar to $\mathbf{1}$, the structure of $\mathbf{2}$ was also elucidated as a prenyleudesmane-type diterpene. Unlike the chemical shifts of position 2 in $1\left(\delta_{\mathrm{C}} 20.1\right.$ and $\delta_{\mathrm{H}}$ $1.56 / 1.58(\mathrm{H}-2 \beta / \mathrm{H}-2 \alpha$, respectively)), the corresponding structural elements in 2 were an oxygenated methylene $\left(\delta_{\mathrm{C}} 68.2\right)$ and a hydroxymethine $\left(\delta_{\mathrm{H}} 4.28, \mathrm{H}-2\right)$. Thus, 2 was determined as the C-2 hydroxylated derivative of $\mathbf{1}$, as shown in Figure 1 . The stereochemistry at C-2 was established by 
the occurrence of NOE correlations between $\mathrm{H}_{3}-19, \mathrm{H}_{3}-20 \mathrm{H}_{3}-18$, and $\mathrm{H}-2$ which indicated a cofacial orientation. Hence, the absolute configuration for C-2 was assigned, based on the X-ray determined configuration of 1, as $R$-configured. Due to the occurrence of similar chemical shifts for C-4, C-5, C-7, C-10, and C-11, as seen in Table 1, similar NOESY correlations, as seen in Figure 2, similar values for the optical rotation, and the above defined configuration of $\mathrm{C} 2$, compound 2 was determined as (2R,4R,5R,7R,10R)-4,10-dimethyl-7-(11R-hydroxy-11,15-dimethyl-14-ene-11-yl)-trans-decalin-2,4-diol, and named lonimacranthoidin $\mathrm{D}(2)$.

The molecular formula of compound 3 was assigned as $\mathrm{C}_{24} \mathrm{H}_{38} \mathrm{O}_{4}$ by its positive HR-ESI-MS data $\left(m / z\right.$ 413.2667, $[\mathrm{M}+\mathrm{Na}]^{+}$; calculated: 413.2662), which indicated six unsaturations in the molecule. Compound 3 was obtained as colorless crystals with an UV spectrum having an absorption maximum at $\lambda_{\max } 243 \mathrm{~nm}$. The compound showed a positive optical rotation of $[\alpha]_{\mathrm{D}}^{25}+12.6$ (c 0.100 in methanol). The ${ }^{1} \mathrm{H}$ NMR spectrum of 3 showed resonances of two olefinic protons at $\delta_{\mathrm{H}} 6.31(1 \mathrm{H}, \mathrm{d}, J=6.0 \mathrm{~Hz}$, $\mathrm{H}-11)$ and $\delta_{\mathrm{H}} 5.49(1 \mathrm{H}, \mathrm{d}, J=5.0 \mathrm{~Hz}, \mathrm{H}-7)$, six methyl resonances at $\delta_{\mathrm{H}} 0.57\left(3 \mathrm{H}, \mathrm{s}, \mathrm{H}_{3}-18\right), \delta_{\mathrm{H}} 1.06(3 \mathrm{H}$, $\left.\mathrm{s}, \mathrm{H}_{3}-19\right), \delta_{\mathrm{H}} 1.21\left(3 \mathrm{H}, \mathrm{d}, J=6.2 \mathrm{~Hz}, \mathrm{H}_{3}-21\right), \delta_{\mathrm{H}} 0.90\left(3 \mathrm{H}, \mathrm{s}, \mathrm{H}_{3}-22\right), \delta_{\mathrm{H}} 1.02\left(3 \mathrm{H}, \mathrm{s}, \mathrm{H}_{3}-23\right)$, and $\delta_{\mathrm{H}} 0.91$ $\left(3 \mathrm{H}, \mathrm{s}, \mathrm{H}_{3}-24\right)$, four hydroxymethines at $\delta_{\mathrm{H}} 3.57(1 \mathrm{H}, \mathrm{d}, J=10.0 \mathrm{~Hz}, \mathrm{H}-1), \delta_{\mathrm{H}} 3.48(1 \mathrm{H}, \mathrm{dd}, J=10.0 / 10.0$ $\mathrm{Hz}, \mathrm{H}-2), \delta_{\mathrm{H}} 3.04(1 \mathrm{H}, \mathrm{d}, J=10.0 \mathrm{~Hz}, \mathrm{H}-3)$, and $\delta_{\mathrm{H}} 3.62(1 \mathrm{H}, \mathrm{dd}, J=6.2 / 9.0 \mathrm{~Hz}, \mathrm{H}-20)$, and further overlapping aliphatic methylenes and/or methines in the range $\delta_{\mathrm{H}} 1.10$ to $\delta_{\mathrm{H}} 2.30$, which were assigned by means of SELTOCSY experiments (see Supporting Information). The ${ }^{13} \mathrm{C}$ NMR and DEPT spectra of 3 showed the presence of four olefinic carbons at $\delta_{C} 119.1(\mathrm{C}-7), \delta_{\mathrm{C}} 144.0(\mathrm{C}-8), \delta_{\mathrm{C}} 142.1(\mathrm{C}-9)$, and $\delta_{\mathrm{C}}$ 119.1 (C-11). The remaining four MS-predicted unsaturations were assigned to a tetracyclic ring system. In addition, six methyl groups at $\delta_{\mathrm{C}} 15.4(\mathrm{C}-18), \delta_{\mathrm{C}} 15.9(\mathrm{C}-19), \delta_{\mathrm{C}} 22.4(\mathrm{C}-21), \delta_{\mathrm{C}} 15.9(\mathrm{C}-22), \delta_{\mathrm{C}} 27.6$ $(\mathrm{C}-23)$, and $\delta_{\mathrm{C}} 24.9(\mathrm{C}-24)$, four methylenes at $\delta_{\mathrm{C}} 22.4(\mathrm{C}-6), \delta_{\mathrm{C}} 36.4(\mathrm{C}-12), \delta_{\mathrm{C}} 31.1(\mathrm{C}-15)$, and $\delta_{\mathrm{C}} 25.8$ $(\mathrm{C}-16)$, two methines at $\delta_{\mathrm{C}} 47.1(\mathrm{C}-5)$ and $\delta_{\mathrm{C}} 53.0(\mathrm{C}-17)$, four oxygenated methines at $\delta_{\mathrm{C}} 78.4(\mathrm{C}-1)$, $\delta_{\mathrm{C}} 72.9(\mathrm{C}-2), \delta_{\mathrm{C}} 78.7(\mathrm{C}-3)$, and $\delta_{\mathrm{C}} 70.4(\mathrm{C}-20)$, and four quaternary carbons at $\delta_{\mathrm{C}} 38.1(\mathrm{C}-4), \delta_{\mathrm{C}} 43.2$ $(\mathrm{C}-10), \delta_{\mathrm{C}} 42.0(\mathrm{C}-13)$, and $\delta_{\mathrm{C}} 49.9(\mathrm{C}-14)$ were observed. Thus, 3 was assigned as a hexanortriterpene derivative with two trisubstituted double bonds $\left(\Delta^{7}\right.$ and $\left.\Delta^{9}\right)$ and four hydroxyl groups $(\mathrm{OH}-1, \mathrm{OH}-2$, $\mathrm{OH}-3$, and $\mathrm{OH}-20)$. Interpretation of the ${ }^{1} \mathrm{H}-{ }^{1} \mathrm{H}$ COSY data resulted in the identification of four spin systems: H-1/H-2/H-3, H-5/H-6/H-7, H-11/H-12, and H-15/H-16/H-17/H-20/H-21. The HMBC correlations from $\mathrm{H}_{3}-18$ to $\mathrm{C}-12, \mathrm{C}-13, \mathrm{C}-14$, and $\mathrm{C}-17$; from $\mathrm{H}_{3}-19$ to $\mathrm{C}-1, \mathrm{C}-5, \mathrm{C}-9$, and C-10; from $\mathrm{H}_{3}-22$ to $\mathrm{C}-3, \mathrm{C}-4, \mathrm{C}-5$, and $\mathrm{C}-23$; from $\mathrm{H}_{3}-23$ to $\mathrm{C}-3, \mathrm{C}-4, \mathrm{C}-5$, and C-22; and from $\mathrm{H}_{3}-24$ to $\mathrm{C}-8$, C-13, C-14, and C-15 allowed for the positioning of two methyl groups at C-4 and four methyl groups at C-10, C-13, C-14, and C-20, respectively. These data indicated that compound 3 was an unusual hexanorlanostane that had been described earlier as aglycon, from the saponins of the sea cucumber Cucumaria koraiensis [16,17]. The full assignment of all positions in the molecule was accomplished by the interpretation of the HSQC and HMBC data, as seen in Table 1, suggesting that 3 was 1,2,3,20-tetrahydroxy-hexanorlanostan-7, 9(11)-diene, as shown in Figure 1. In the ROESY spectrum of 3, correlations between $\mathrm{H}_{3}-18 / \mathrm{H}_{3}-19 / \mathrm{H}_{3}-23 / \mathrm{H}-2$ and $\mathrm{H}_{3}-22 / \mathrm{H}-3$ indicated that $\mathrm{H}_{3}-18, \mathrm{H}_{3}-19, \mathrm{H}_{3}-23$, and $\mathrm{H}-2$ were on one side of the molecular plane, while $\mathrm{H}_{3}-22$ and $\mathrm{H}-3$ were located on the opposite side. Fortunately, crystals of compound 3 could be obtained and were subjected to single-crystal X-ray diffraction analysis, as seen in Figure 4. Based on our results, the absolute configuration of 3 was determined as $(1 S, 2 S, 3 R, 5 S, 10 S, 13 R, 14 R, 17 S, 20 S)-1,2,3,20$-tetrahydroxy-hexanorlanostan-7, 9(11)-diene (3) by Cu X-ray crystallography (Flack parameter $=0.20(6)$, Figure 4 ) and named lonimacranthoidin E. 


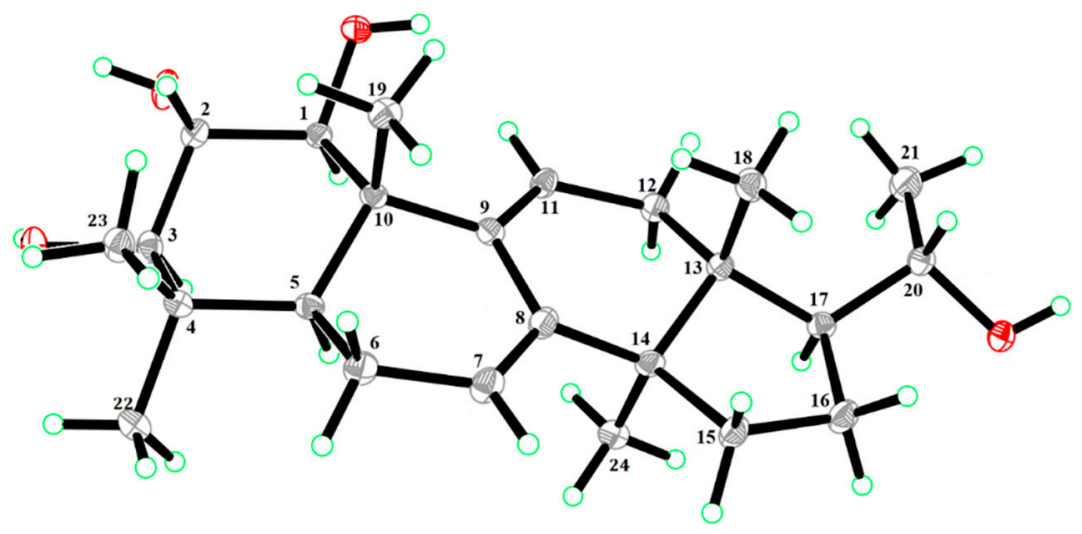

Figure 4. X-ray ORTEP drawing of compound 3.

Compounds 1-3 were furthermore tested for their antiproliferative effect on the Human Hepatocellular Carcinoma Cell lines (HepG2), Human Cervical Carcinoma Cell line (HeLa), and the Human Aortic Smooth Muscle Cell line (HASMC). The results, as seen in Table 2, demonstrated that 1-3 showed moderate antiproliferative activities ( $\mathrm{IC}_{50} 12.5 \pm 0.9$ to $64.9 \pm 3.5 \mu \mathrm{M}$ ) against the two tumor cell lines. No significant effect against HASMC was observed.

Table 2. Antiproliferative activities of compounds 1-3 against two cancer cells and one normal cell line. ${ }^{\text {a. }}$

\begin{tabular}{ccccc}
\hline Cell Line & $\mathbf{1}$ & $\mathbf{2}$ & $\mathbf{3}$ & Etoposide \\
\hline HepG2 & $36.3 \pm 2.1$ & $64.9 \pm 3.5$ & $46.0 \pm 2.4$ & $25.4 \pm 1.7$ \\
HeLa & $13.8 \pm 1.1$ & $27.1 \pm 1.4$ & $12.5 \pm 0.9$ & $21.2 \pm 1.3$ \\
HASMC & $>100$ & $>100$ & $>100$ & 63.7 \\
\hline \multicolumn{5}{c}{}
\end{tabular}

Prenyleudesmanes are a rare class of diterpenes that were originally isolated from marine algae [18,19] and marine mollusks [20-24]. Prenyleudesmanes were also found in fungi [25] and plants of the genus Dysoxylum [13,26-28]. Our report on the isolation and full structure elucidation of lonimacranthoidin C (1) and lonimacranthoidin D (2) from L. macranthoides therefore suggests another source for prenyleudesmanes in nature. Interestingly, the hexanorlanostane 3 was initially found in sea creatures $[16,17]$. Lonimacranthoidin E (3) is the first example of a hexanorlanostane isolated from a terrestrial plant.

\section{Materials and Methods}

\subsection{General Experimental Procedures}

Thin-layer chromatography was carried out on silica gel 60 GF254 (Merck) plates. Preparative HPLC (LC-20AR, Shimadzu, Kyoto, Japan) was conducted on a Shim-pack GIS C 18 column $(5 \mu \mathrm{m}, 250 \times 20 \mathrm{~mm}$, Shimadzu). Column chromatography (CC) was performed on silica gel (200-300 mesh) and Sephadex LH-20. LC-HRMS spectra were obtained from an Agilent 1260 UPLC-DAD-6530 ESI Q-TOF MS (Agilent Technologies GmbH, Waldbronn, Germany). Optical rotation values were measured using a Jasco P-1020 polarimeter. NMR data were obtained using a Bruker Avance $500 \mathrm{MHz}$ or Bruker Avance $300 \mathrm{MHz}$ spectrometers (Bruker Biospin GmbH, Karlsruhe, Germany). Tetramethylsilane was used as an internal standard. The X-ray structures were solved by direct methods (SHELXL-97). The X-ray crystallographic data were collected on a Bruker SMART APEX-II CCD diffractometer using graphite monochromatic $\mathrm{Cu} \mathrm{K}_{\alpha}$ radiation. 


\subsection{Plant Material}

The roots of L. macranthoides were collected from Longhui in the Hunan province of China in July 2015. The plants were taxonomically identified by Professor Changqi Yuan (Institute of Botany, Jiangsu province and Chinese Academy of Sciences). A voucher specimen (No. 20150701) has been deposited in the herbarium of the Institute of Botany, Jiangsu province, and Chinese Academy of Sciences.

\subsection{Extraction and Isolation}

The dried roots $(4.0 \mathrm{~kg}$ ) of L. macranthoides were milled and repeatedly extracted with $95 \% \mathrm{EtOH}$ for $2 \mathrm{~h}$ under reflux $\left(80^{\circ} \mathrm{C}\right)$. After evaporation in vacuo, the crude extract $(472.6 \mathrm{~g})$ was resuspended in $\mathrm{H}_{2} \mathrm{O}$ and partitioned with petroleum ether and ethyl acetate (EtOAc), in succession. The EtOAc fraction (94 g) was subjected to column chromatography (silica gel, $\mathrm{CH}_{2} \mathrm{Cl}_{2}-\mathrm{MeOH}$ 100:0-0:100) to produce six fractions (F1-F6) on the basis of TLC analysis. F2 (21 g) was purified by column chromatography on Sephadex LH-20 $\left(\mathrm{CH}_{2} \mathrm{Cl}_{2}-\mathrm{MeOH}, 1: 1\right)$, followed by preparative HPLC using $\mathrm{MeOH}-\mathrm{H}_{2} \mathrm{O}(65: 35$, $v / v$, flow rate $1.0 \mathrm{~mL} / \mathrm{min})$ as an eluent to obtain the compounds $1(11.0 \mathrm{mg})$ and $2(6.0 \mathrm{mg}) . \mathrm{F} 5(11 \mathrm{~g})$ was purified by preparative HPLC with $\mathrm{MeOH}-\mathrm{H}_{2} \mathrm{O}(55: 45, v / v$, flow rate $3.0 \mathrm{~mL} / \mathrm{min})$ as an eluent to obtain compound 3 (13.0 mg).

\subsection{Compound Characterization}

Lonimacranthoidin C (1): colorless crystals $(\mathrm{MeOH}) ;[\alpha]_{\mathrm{D}}^{25}+26.4$ (c 0.100 in $\left.\mathrm{MeOH}\right) ; \mathrm{UV}(\mathrm{MeOH})$ $\lambda_{\max } 201 \mathrm{~nm}$; mp 101-103 ${ }^{\circ} \mathrm{C}$; HR-ESI-MS m/z 331.2607 [M + Na] ${ }^{+}$(calculated for $\mathrm{C}_{20} \mathrm{H}_{36} \mathrm{O}_{2}:$ 331.2608); ${ }^{1} \mathrm{H} \mathrm{NMR}\left(500 \mathrm{MHz}, \mathrm{CDCl}_{3}\right)$ and ${ }^{13} \mathrm{C} \mathrm{NMR} \mathrm{(125} \mathrm{MHz,} \mathrm{CDCl}_{3}$ ) spectroscopic data, see Table 1. Lonimacranthoidin C (1) was recrystallized in methanol/ethyl acetate (3:1). A single-crystal X-ray diffraction analysis using $\mathrm{Cu} \mathrm{K} \alpha$ radiation $(1.54178 \AA)$ was carried out to confirm the structure. $M=308.49$, monoclinic, $\mathrm{P} 2{ }_{1} 2{ }_{1} 21, a=11.5498$ (17) $\AA, b=12.2435$ (14) $\AA, c=27.246$ (3) $\AA, \alpha=\gamma=\beta=90.00^{\circ}$, $V=3852.8(9) \AA^{3}, Z=8, D c=1.064 \mathrm{mg} \mathrm{mm}^{-3}, T=153(2) \mathrm{K}, F(000)=1376.0$. The crystallographic data centre has assigned the code Cambridge Crystallographic Data Centre (CCDC) 1,941,729 for the crystal structure of lonimacranthoidin C (1). The CCDC contains the supplementary crystallographic data for this paper. These data can be obtained free of charge via http://www.ccdc.cam.ac.uk/conts/retrieving. html.

Lonimacranthoidin D (2): milky oil (MeOH); $[\alpha]_{\mathrm{D}}^{25}+10.0$ (c 0.100 in MeOH); UV (MeOH) $\lambda_{\max }$ $201 \mathrm{~nm}$; HR-ESI-MS m/z 347.2551 [M + Na] ${ }^{+}$(calculated for $\left.\mathrm{C}_{20} \mathrm{H}_{36} \mathrm{O}_{3}, 347.2557\right) ;{ }^{1} \mathrm{H} \mathrm{NMR}(500 \mathrm{MHz}$, $\left.\mathrm{CDCl}_{3}\right)$ and ${ }^{13} \mathrm{C}$ NMR $\left(125 \mathrm{MHz}, \mathrm{CDCl}_{3}\right)$ spectroscopic data are listed in Table 1.

Lonimacranthoidin E (3): colorless crystals $(\mathrm{MeOH}) ;[\alpha]_{\mathrm{D}}^{25}+12.6$ (c 0.100 in $\left.\mathrm{MeOH}\right) ; \mathrm{UV}(\mathrm{MeOH})$ $\lambda_{\max } 243 \mathrm{~nm}$; $\mathrm{mp} 244-246{ }^{\circ} \mathrm{C}$; HR-ESI-MS m/z $413.2667[\mathrm{M}+\mathrm{Na}]^{+}$(calculated for $\mathrm{C}_{24} \mathrm{H}_{38} \mathrm{O}_{4}:$ 413.2662); ${ }^{1} \mathrm{H} \mathrm{NMR}\left(300 \mathrm{MHz}\right.$, in $\left.\mathrm{CDCl}_{3}: \mathrm{CD}_{3} \mathrm{OD}=1: 1\right)$ and ${ }^{13} \mathrm{C} \mathrm{NMR}\left(75 \mathrm{MHz}\right.$, in $\left.\mathrm{CDCl}_{3}: \mathrm{CD}_{3} \mathrm{OD}=1: 1\right)$, for NMR spectroscopic data, see Table 1. Lonimacranthoidin E (3) was re-crystallized in methanol/ethyl acetate (1:1). A single-crystal X-ray diffraction analysis using $\mathrm{Cu} \mathrm{K} \alpha$ radiation $(1.54178 \AA$ ) was carried out to confirm the structure. $M=390.54$, monoclinic, $\mathrm{P} 2{ }_{1} 2_{1} 2_{1}, a=6.0714$ (4) $\AA, b=13.2797$ (8) $\AA, c=28.6232$ (17) $\AA, \alpha=\gamma=\beta=90.00^{\circ}, V=2307.87$ (2) $\AA^{3}, Z=4, D c=1.124 \mathrm{mg} \mathrm{mm}^{-3}, T=153(2) \mathrm{K}, F(000)=856$. The crystallographic data centre has assigned the code CCDC 1,941,730 for the crystal structure of lonimacranthoidin E (3) The CCDC contains the supplementary crystallographic data for this paper. These data can be obtained free of charge via http://www.ccdc.cam.ac.uk/conts/retrieving.html.

\subsection{Biological Assay}

HepG2, HeLa, and HASMC cell lines were cultured in Dulbecco's modified Eagle's medium (Gibco, Grand Island, NY, USA) supplemented with 10\% fetal bovine serum (Gibco), $100 \mu \mathrm{g} / \mathrm{mL}$ penicillin, and $100 \mu \mathrm{g} / \mathrm{mL}$ streptomycin. The cells were cultivated in a humidified atmosphere of $5 \%$ $\mathrm{CO}_{2}$ at $37^{\circ} \mathrm{C}$. Antiproliferative assays of the compounds 1-3 against the above-mentioned three cell 
lines were evaluated using the 3-(4,5-dimethylthiazol-2-yl)-2,5-diphenyltetrazoliumbromide (MTT) assay, carried out according to protocols [29] described previously.

Supplementary Materials: ${ }^{1} \mathrm{H}$ and ${ }^{13} \mathrm{C}$ NMR, ${ }^{13} \mathrm{C}-\mathrm{DEPT},{ }^{1} \mathrm{H}-{ }^{13} \mathrm{C}$ HSQC,${ }^{1} \mathrm{H}-{ }^{13} \mathrm{C}$ HMBC, ${ }^{1} \mathrm{H}^{-1} \mathrm{H}$ COSY, ${ }^{1} \mathrm{H}-{ }^{1} \mathrm{H}$ ROESY, SELTOCSY, UV, and HR-ESI-MS data of compounds 1-3 are available in the Supporting Information.

Author Contributions: Funding acquisition, X.F. and Y.C.; Investigation, H.L., W.L., B.B., Y.S. and C.P.; Methodology, Y.C.; Project administration, Y.C.; Supervision, X.F. and Y.C.; Writing-original draft, H.L.; Writing-review \& editing, C.P. and Y.C.

Acknowledgments: This research was supported financially by the National Natural Science Foundation of China (31770383, 31970375) and Research Project of 333 High-Level Talents Cultivation of Jiangsu Province (BRA2016463). We thank Emily Wheeler for editorial assistance.

Conflicts of Interest: The authors declare no conflict of interest.

\section{References}

1. FOC (Flora of China) Flora of China Website. 1988. Available online: http://frps.iplant.cn/frps/Lonicera\% 20macranthoides (accessed on 15 October 2019).

2. Chinese Pharmacopeia Commission. Pharmacopeia of the People's Republic of China; China Medical Science Press: Beijing, China, 2015; Volume 1, p. 30.

3. Chen, Y.; Zhao, Y.; Wang, M.; Wang, Q.; Shan, Y.; Guan, F.; Feng, X. A new lupane-type triterpenoid saponin from Lonicera macranthoides. Chem. Nat. Compd. 2014, 49, 1087-1090. [CrossRef]

4. Chen, Y.; Feng, X.; Jia, X.; Wang, M.; Liang, J.; Dong, Y. Triterpene glycosides from Lonicera. Isolation and structural determination of seven glycosides from flower buds of Lonicera macranthoides. Chem. Nat. Compd. 2008, 44, 39-43. [CrossRef]

5. Chen, Y.; Feng, X.; Wang, M.; Zhao, Y.Y.; Dong, Y.F. Triterpene glycosides from Lonicera. II. Isolation and structural determination of glycosides from flower buds of Lonicera macranthoides. Chem. Nat. Compd. 2009, $45,514-518$.

6. Chen, Y.; Shan, Y.; Zhao, Y.Y.; Wang, Q.Z.; Wang, M.; Feng, X.; Liang, J.Y. Two new triterpenoid saponins from Lonicera macranthoides. Chin. Chem. Lett. 2012, 3, 325-328. [CrossRef]

7. Sun, M.; Feng, X.; Yin, M.; Chen, Y.; Zhao, X.; Dong, Y. A biflavonoid from stems and leaves of Lonicera macranthoides. Chem. Nat. Compd. 2012, 48, 231-233. [CrossRef]

8. Sun, M.; Feng, X.; Lin, X.H.; Yin, M.; Zhao, X.Z.; Chen, Y.; Shan, Y. Studies on the chemical constituents from stems and leaves of Lonicera macranthoides. J. Chin. Med. Mater. 2011, 34, 218-220.

9. Liu, J.; Zhang, J.; Wang, F.; Chen, X.F. Chemical constituents from the buds of Lonicera macranthoides in Sichuan, China. Biochem. Syst. Ecol. 2014, 54, 68-70. [CrossRef]

10. Liu, W.J.; Chen, Y.; Ma, X.; Zhao, Y.Y.; Feng, X. Study on chemical constituents from roots of Lonicera macranthoides. Chin. Med. Mat. 2014, 37, 2207-2209.

11. Bai, B.; Chen, Y.; Liu, W.J.; Yin, M.; Wang, M.; Feng, X. Chemical constituents of petroleum ether fraction of Lonicera macranthoides roots. J. Chin. Med. Mater. 2015, 38, 518-520.

12. Lyu, H.; Liu, W.J.; Xu, S.; Shan, Y.; Feng, X.; Chen, Y. Two 9, 10-syn-pimarane diterpenes from the roots of Lonicera macranthoides. Phytochem. Lett. 2018, 25, 175-179. [CrossRef]

13. Fujioka, T.; Yamamoto, M.; Kashiwada, Y.; Fujii, H.; Mihashi, K.; Ikeshiro, Y.; Chen, I.S.; Lee, K.H. Novel cytotoxic diterpenes from the stem of Dysoxylum kuskusense. Bioorg. Med. Chem. Lett. 1998, 8, 3479-3482. [CrossRef]

14. Flack, H.D. On enantiomorph-polarity estimation. Acta. Cryst. A Found. Crystallogr. 1983, 39, 876-881. [CrossRef]

15. Flack, H.D.; Bernardinelli, G. Reporting and evaluating absolute-structure and absolute-configuration determinations. J. Appl. Crystallogr. 2000, 33, 1143-1148. [CrossRef]

16. Avilov, S.A.; Kalinovsky, A.I.; Kalinin, V.I.; Stonik, V.A.; Riguera, R.; Jiménez CKoreoside, A. A new nonholostane triterpene glycoside from the sea cucumber Cucumaria koraiensis. J. Nat. Prod. 1997, 60, 808-810. [CrossRef] [PubMed]

17. Kalinin, V.I.; Silchenko, A.S.; Avilov, S.A.; Stonik, V.A. Non-holostane aglycones of sea cucumber triterpene glycosides. Structure, biosynthesis, evolution. Steroids 2018, 147, 42-51. [CrossRef] [PubMed] 
18. Sun, H.H.; Waraszkiewicz, S.M.; Erickson, K.L.; Finer, J.; Clardy, J. Dictyoxepin and dictyolene, two new diterpenes from the marine alga Dictyota acutiloba (Phaeophyta). J. Am. Chem. Soc. 1977, 99, 3516-3517. [CrossRef]

19. Takahashi, Y.; Suzuki, M.; Abe, T.; Masuda, M. Anhydroaplysiadiol from Laurencia japonensis. Phytochemistry 1998, 48, 987-990. [CrossRef]

20. Ojika, M.; Yoshida, Y.; Okumura, M.; Ieda, S.; Yamada, K. Aplysiadiol, A new brominated diterpene from the marine mollusc Aplysia kurodai. J. Nat. Prod. 1990, 53, 1619-1622. [CrossRef]

21. Matthée, G.F.; König, G.M.; Wright, A.D. Three new diterpenes from the marine soft coral Lobophytum crassum. J. Nat. Prod. 1998, 61, 237-240. [CrossRef]

22. Cheng, S.Y.; Chuang, C.T.; Wang, S.K.; Wen, Z.H.; Chiou, S.F.; Hsu, C.H.; Dai, C.F.; Duh, C.Y. Antiviral and anti-inflammatory diterpenoids from the soft coral Sinularia gyrosa. J. Nat. Prod. 2010, 73, 1184-1187. [CrossRef]

23. Li, L.; Sheng, L.; Wang, C.Y.; Zhou, Y.B.; Huang, H.; Li, X.B.; Li, J.; Molllo, E.; Gavagnin, M.; Guo, Y.W. Diterpenes from the Hainan soft coral Lobophytum cristatum Tixier-Durivault. J. Nat. Prod. 2011, 74, 2089-2094. [CrossRef] [PubMed]

24. Ye, F.; Zhu, Z.D.; Gu, Y.C.; Li, J.; Zhu, W.L.; Guo, Y.W. Further new diterpenoids as PTP1B inhibitors from the Xisha soft coral Sinularia polydactyla. Mar. Drugs 2018, 16, 103. [CrossRef] [PubMed]

25. Liu, D.Z.; Liang, B.W.; Li, X.F.; Liu, Q. Induced production of new diterpenoids in the fungus Penicillium funiculosum. Nat. Prod. Commun. 2014, 9, 607-608. [CrossRef] [PubMed]

26. Duh, C.Y.; Wang, S.K.; Chen, I.S. Cytotoxic prenyleudesmane diterpenes from the fruits of Dysoxylum kuskusense. J. Nat. Prod. 2000, 63, 1546-1547. [CrossRef]

27. Gu, J.; Qian, S.Y.; Zhao, Y.L.; Cheng, G.G.; Hu, D.B.; Zhang, B.H.; Liu, Y.P.; Luo, X.D. Prenyleudesmanes, rare natural diterpenoids from Dysoxylum densiflorum. Tetrahedron 2014, 70, 1375-1382. [CrossRef]

28. Zhang, P.; Lin, Y.; Wang, F.; Fang, D.; Zhang, G. Diterpenes from Dysoxylum lukii Merr. Phytochem. Lett. 2019, 29, 53-56. [CrossRef]

29. Alley, M.C.; Scudiero, D.A.; Monks, A.; Hursey, M.L.; Czerwinski, M.J.; Fine, D.L.; Abbott, B.J.; Mayo, J.G.; Shoemaker, R.H.; Boyd, M.R. Feasibility of drug screening with panels of human tumor cell lines using a microculture tetrazolium assay. Cancer Res. 1998, 48, 589-601.

Sample Availability: Samples of the compounds $\mathbf{1}$ and $\mathbf{3}$ are available from the authors.

(C) 2019 by the authors. Licensee MDPI, Basel, Switzerland. This article is an open access article distributed under the terms and conditions of the Creative Commons Attribution (CC BY) license (http://creativecommons.org/licenses/by/4.0/). 